\title{
Collaborations between Engineers and Artists in the Making of Computer Art in Sweden, 1967-1986
}

\author{
Anna Orrghen \\ Dept. of Art History, Uppsala University, Box 630, 75126 Uppsala, Sweden \\ anna.orrghen@konstvet.uu.se
}

\begin{abstract}
The aim of this paper is to describe and analyze collaborations between artists and engineers working together in the making of computer art in Sweden 1967-1986. The paper is based on interviews with artists and engineers who collaborated during this time. By using the theoretical concept "coconstruction," I map the phenomenon and discuss the driving forces behind the social, as well as the economical and institutional conditions of the collaborations.
\end{abstract}

Keywords: Art and technology, art and science, computer art, computer pioneers, human computer interaction.

\section{Introduction}

During the mid-1960s, when artists started to gain access to computer departments at universities and research departments in large industrial companies, a new kind of collaborations between artists and engineers developed [1]. Next to the US, Germany and Great Britain, Sweden is put to the fore as one of the countries where artists and engineers at an early stage explored the possibilities of using computers for creating art $[2,3]$. For instance, the programmer Göran Sundqvist at Saab in Linköping, and later at AB Skandinaviska Elverk, used the Saab manufactured computer D21 at Skandinaviska Elverk to help the composer and artist Jan W Morthenson. He also used the ABC 80 computer with a XY-plotter for collaboration with the composer and artist Lars-Gunnar Bodin. Another example is the long-term collaboration between IBM employed programmer Sten Kallin and the artist Sture Johannesson, which began in 1969 and resulted in the projects Intra and Exploring Picture Space (EPICS). Johannesson and Kallin worked with Intra at IBM in Stockholm where they used an IBM 1130 computer to elaborate on different kind of patterns. A third example is Mikael Jern who developed the program Color for the Color Ink Jet Plotter at the computer department at Lund University in 1970s. The artists Beck \& Jung, among others, used Color on a UNIVAC 1108 for making computer art.

We can regard contemporary art in general and computer art in particular as complex negotiation processes between artists and other actors. The foundation of the American organization Experiments in Art and Technology (E.A.T.) in 1966 and their famous event 9 Evenings: Theatre and Engineering in October that same year must be considered as crucial events regarding the changing possibilities for these kinds of 
collaborations [4]. Art today increasingly seems to turn into interdisciplinary projects involving a number of different actors.

How can we understand these collaborations? In this paper, I use the insights made within the interdisciplinary field of Science and Technology Studies (STS). A basic assumption in the STS approach is that we should describe scientific and technological activities as the result of relations between different actors rather than the result of singular individuals, disciplines or groups. By adopting such a perspective, we regard scientific knowledge and its use as a conscious cooperation between different actors who produce and use this knowledge [5].

An STS concept particularly apt to study collaborations between different actors is "co-construction." Nelly Oudshoorn and Trevor Pinch introduced the concept in their book How Users Matter from 2003. Their main argument is that researchers interested in users and technology had a narrowly focused view on users as separate objects of study. By using the term co-construction as a point of departure, they aim at changing the perspective and instead, they underscore the development of new products as a cooperation effort between "producers" and "consumers" and that the use of the products is the result of a negotiating process between these two groups. Hence, the term emphasizes the importance of studying production and consumption of knowledge together rather than as separate phenomena. Oudshoorn and Pinch pay attention to the role of the user in technological development in general and they are interested in how users consume, modify and resist technologies. Although their primary focus includes "what users do with technology," they are also interested in "what technology does with users" [6].

The aim of this paper is to describe and analyze collaborations between artists and engineers working together in the making of computer art in Sweden 1967-1986. Earlier, the Swedish art historian Gary Svensson has studied the introduction of computer art in Sweden. Although he also mentions that the collaborations took place, he focuses mainly on mapping the actors and the art works, as well as placing the Swedish development in an art historical context [7]. In my approach, on the other hand, attention is paid to the collaborations only. I am particularly interested in questions on three different levels. The first one deals with mapping the phenomenon, i.e. which artists and engineers participated in collaborations and which art works did they create during those collaborations? The second one concerns the driving forces behind the collaborations: Why did they collaborate? What did they expect to gain and what did they gain from the collaborations? How do they consider their role in the collaboration? What impact did the collaboration have on their work as artists as well as engineers?

The third question includes the social, economic, and institutional conditions of the collaborations. How did the artists and engineers get into contact? How did they carry through the collaboration? Where did it take place? Which computers did they use? How did they finance the collaborations? By taking Oudshoorn and Pinch's concept co-construction as a theoretical point of departure, I shed light upon these questions from the point of view of the artists as well as the engineers. I argue that early Swedish computer art illustrates a kind of co-constructed contemporary art.

The sources for this paper are mainly interviews with Swedish artists and engineers who collaborated to create computer art. I conducted these interviews within the documentation project "From Computing Machines to IT." The project aimed at 
documenting the Swedish IT history; it was collaboration between the Div. of History of Technology at KTH in Stockholm, the National Museum of Science, and Technology in Stockholm and the Swedish Computer Society [8].

Although these oral sources are necessary to be able to study these collaborations, there are, however, a number of difficulties concerning source criticism related to interviews as a methodology. One such difficulty concerns how the researcher is to relate to an interview conducted several years after the case in question. This underlines the importance of being aware of memory and time in relation to oral history as a method [9]. However, one way of dealing with this question is to supplement the oral sources with written sources.

\section{Three Case Studies}

This paper contains three case studies followed by a concluding discussion.

\subsection{Case 1: Göran Sundqvist, Jan W Morthenson and Lars-Gunnar Bodin}

One of the earliest collaborations took place between the programmer Göran Sundqvist (b. 1937) and the composer and artist Jan W Morthenson (b. 1940). Sundqvist, at Saab in Linköping, and later at AB Skandinaviska Elverk, used the Saab manufactured computer D21 at Skandinaviska Elverk to create a digital sound for Morthenson's musical piece Neutron Star in 1967. In 1969, Sundqvist made the computer animations for Supersonics, a TV-film Morthenson made for Westdeutscher Rundfunk [7, 10, 11]. Morthenson met Sundqvist at Fylkingen, a society committed to experimental and unestablished forms of contemporary art, where the latter's musical experiments with the computer D21 had gained him a reputation for being interested in the field of art, music and computers [11]. At Fylkingen, Sundqvist also made acquaintance with the composer and artist Lars-Gunnar Bodin (b. 1935). In 1968, he used the Saab manufactured computer D21 at Skandinaviska Elverk to realize Bodin's work on stochastic compositions and in 1979, the collaboration continued, although this time Sundqvist used the ABC 80 computer with a XY-plotter to continue the elaboration on the same theme.

Morthenson and Bodin nursed an interest in new aesthetic expressions, which led them to the computer. Although they lacked access to computers, they were both well acquainted with the international development within the field and they had ideas of how to use this new technology for artistic purposes. Sundqvist, who earlier had elaborated with SARA at Saab and later with D21 at AB Skandinaviska Elverk, also shared this interest to create sound and images. Hence, the main reason for Morthenson and Bodin to approach Sundqvist was twofold: he could offer access to a computer, and he knew how to use it. Alternatively, as Morthenson puts it: "He was important since he was the first one who could offer access to a computer, a so called D21" [11]. Even though Sundqvist, Morthenson and Bodin shared a mutual interest in the artistic possibilities of computer technology, it is nonetheless clear that they had different roles. Describing their roles during the work with Supersonics, Morthenson says, "I drew pictures and courses [of events], pretty much the same thing as when one makes an animated movie. I made him a storyboard and then he tried to realize it as well as he could by using the oscilloscope" [11]. Moreover, when Sundqvist 
describes their collaboration on Neutron Star, he says, "He wanted short sound beats with a number of different frequencies, and I made that" [12]. Afterwards, Morthenson himself put the piece together. The collaboration with Bodin follows a similar pattern which Bodin expresses, "I gave a number of rules for how these should be" [13], and Sundqvist explains, "I was curious and he had ideas" [12].

The quotations illustrate their different roles where they asked Sundqvist to perform a specific task that made it possible for the artists to realize their ideas. Sundqvist's description of his role in the collaborations is similar to his description of the working tasks that he received and carried through at Saab and AB Skandinaviska Elverk. There he occasionally was asked to elaborate on the computer, preferably by creating sound and images to demonstrate its possibilities for presumable clients. In 1960, he received a similar task to impress on a group from the military air force interested in the computer D2:

... [Bernt Magnusson] gave me the equation of a trajectory, and I managed to draw it by the help of sub programs for sinus and cosinus that they used on SARA, the large copy of BESK at SAAB. [...] I kept on experimenting with it for many years after that, in order to make different pictures [12].

Today, the program described is probably considered the first computer game created in Sweden [14]. I would like to dwell upon the later part of Sundqvist's answer, which I find particularly interesting. On one hand, he received instructions and followed them, but on the other hand, he also used these instructions as a springboard to continue to elaborate on and develop his knowledge of how to create sound and images with the computer for his own sake of interest. Of course, it is not possible to say whether those collaborations really contributed to Sundqvist's development as a programmer. However, considering that he carried out these tasks in a similar way as he did at AB Skandinaviska Elverk and Saab, and that he wrote his own programs to realize Morthenson's and Bodin's artistic ideas, one might assume that this was the case.

Financially, AB Skandinaviska Elverk sponsored the collaborations since Sundqvist could use their computers. Although Sundqvist often used the D21 in his spare time, occasionally he also used it during working hours while waiting for the result of his programming to appear [12].

\subsection{Case 2: Sten Kallin and Sture Johannesson}

In 1969, the artist Sture Johannesson (b. 1935) approached IBM in Sweden. Inspired by the development in the U.S., where the computers were reported to be able to "draw pictures," Johannesson was anxious to find out more about this new technology and its possibilities. The request ended up at Sten Kallin's (b. 1928) desk and became the starting point of a long time collaboration that resulted in the projects Intra (1969-1974) and EPICS (1986-present) [15]. Kallin was an instructor in programming languages and program design and development, a "systems engineer," and in the 1980s "senior consultant." Similar to Sundqvist, Kallin was well known among his colleagues at IBM because of his interest in elaborating with the computer for his own sake, and thus he had gained a reputation to have "some strange ideas and projects going on" [16]. 
Before Johannesson contacted IBM, he had elaborated with a number of different artistic techniques such as painting, drawing, screen print and clay. The subjects of the pictures were often taken from an "alphabet" he had developed containing different symbols, e.g. a key, a heart and a combination of both. With Intra he continued to elaborate on these symbols in yet another technique: computer technology. Johannesson and Kallin worked with Intra at IBM in Stockholm where they used an IBM 1130 computer to elaborate on graphical pictures constructed by mathematical curves.

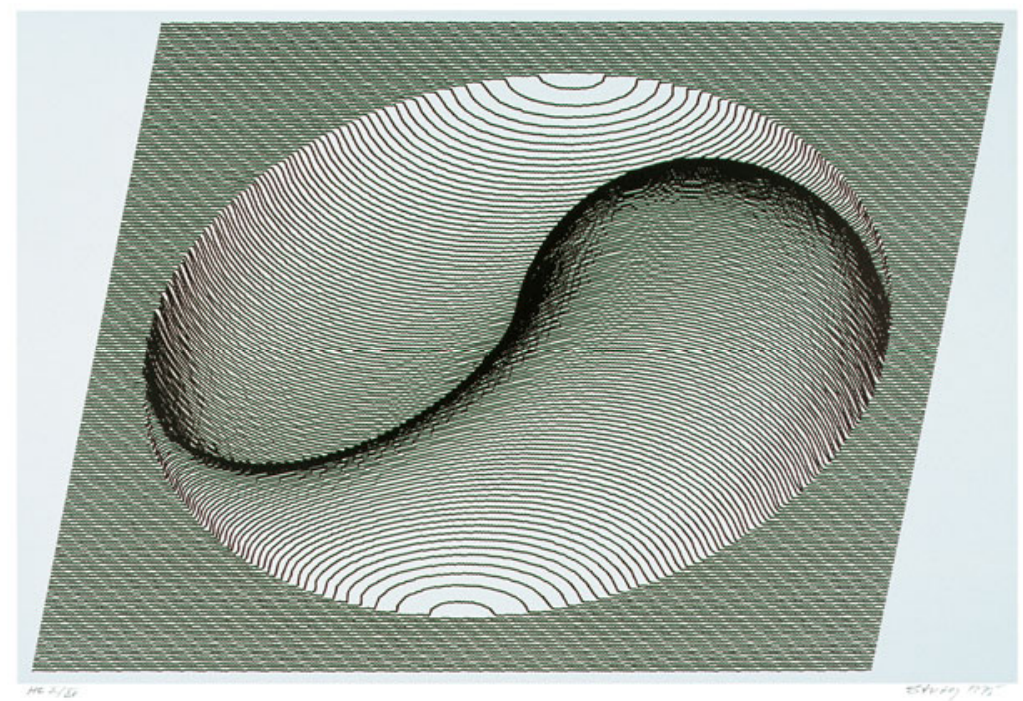

Fig. 1. Spirals 106, from Intra 1969/70-1974. Courtesy of Sture Johannesson

In 1986, Kallin's and Johannesson's second project started, EPICS [7, 16]. EPICS was carried out with a PC-AT and a graphic screen. However, this time, Kallin approached Johannesson by saying:

I think we should make a project together, I have an idea. And I think we should continue our exploring of a picture space. But not a picture space with the keyhole, the heart and stuff like that, because it's difficult to figure out how we could develop it. My idea is that we let simple graphic elements on a picture space be surrounded by some kind of aesthetical power field, a power field similar to gravitation or an electrostatic field that reduces by distance. [...] And I would like to elaborate on this aesthetical power field and be able to visualize it graphically in one way or another. [---] And he jumped at it and we gave it a thought and made a number of suggestions and I probably made a simple prototype of something. After that we went to IBM and said that we would like to do this. I will only do it during my spare time but Sture needs equipment. IBM Malmö lends him a pretty good PC-AT, the third generation of IBM PC's and a graphic screen [16]. 
Kallin's thorough description of how EPICS started and how it was realized puts to the fore a number of interesting things. For instance, it illustrates the interaction that was taking place between Kallin's involvement in artistic projects and his regular working tasks at IBM. Kallin's driving forces behind the collaboration were twofold. On one hand, he was interested in "the huge possibilities of visualizing with the help of computer technology" [17]. On the other, he had always been interested in solving problems. By collaborating with Johannesson he gained new experiences of how to visualize with the computer. Some might interpret the fact that he wanted to continue the collaboration to develop his newly achieved skills as a sign of the impact of the collaboration on his work as an engineer. Kallin confirms the interpretation by claiming, "Yes indeed. Everything I have done has taught me a lot one can use later on" [16].

An interest in visualizing by using new technology was also the main driving force for Johannesson. Before Johannesson started to work with Kallin he had tried different printing techniques. Hence, turning to the computer should be a natural step in his artistic development. However, another important factor needs mentioning. Before contacting IBM, Johannesson had gained a reputation of being a troublemaker, which, according to himself, froze him out within the art world. Contacting IBM was for him a way of finding a new arena "free of prejudices" where he could continue to elaborate with his art [18].

Given that Johannesson initiated Intra and Kallin initiated EPICS, makes the question of their different roles particularly apt to study. On one hand, one can easily assign them different roles where Kallin possessed the technical knowledge and access to computer technology and Johannesson had a broader experience of visualizing in different techniques. There is, however, another question brought to the fore by Kallin who touches upon a highly interesting, yet difficult, question of creativity while describing the collaboration:

I completed the program but gave him as many parameters as I could, so he could do that on his own, so he would feel that at least he was participating. That is of course a sensitive question concerning creativity, where the creativity is... And I do think that the main creativity comes from the one who designs the program since that is the one who completely decides the frames [16].

Thus, on the other hand it is much harder to claim one of the roles as the more creative one. Kallin's description of his interest and involvement in what became EPICS makes their collaboration an interesting illustration of Oudshoorn's and Pinch's co-construction. Although Kallin initiated EPICS and had a clear idea of what he wanted to do, he needed Johannesson's artistic experience to realize his ideas, just as Johannesson needed Kallin's knowledge of and access to computers.

However, Kallin's description also tells something about the economical conditions of the collaboration. Economically, IBM financed the collaboration in terms of allowing Kallin to use their computers. IBM also sponsored Johannesson's participation in a couple of international conferences in Denmark, Germany and Switzerland where he and Kallin demonstrated EPICS as well as lent him the technical equipment he needed. One might also talk about an important institutional support from IBM since according to Kallin the collaboration was "heavily supported" [16] by the information department at IBM that also initiated the contact 
between Kallin and Johannesson. This institutional support also reflects when Johannesson describes IBM as a space free of prejudices against him where he contrary to the art world - was trusted and given an artistic freedom: "I borrowed a key to IBM's laboratory in Solna and went there by myself and unlocked and locked when I left" [18].

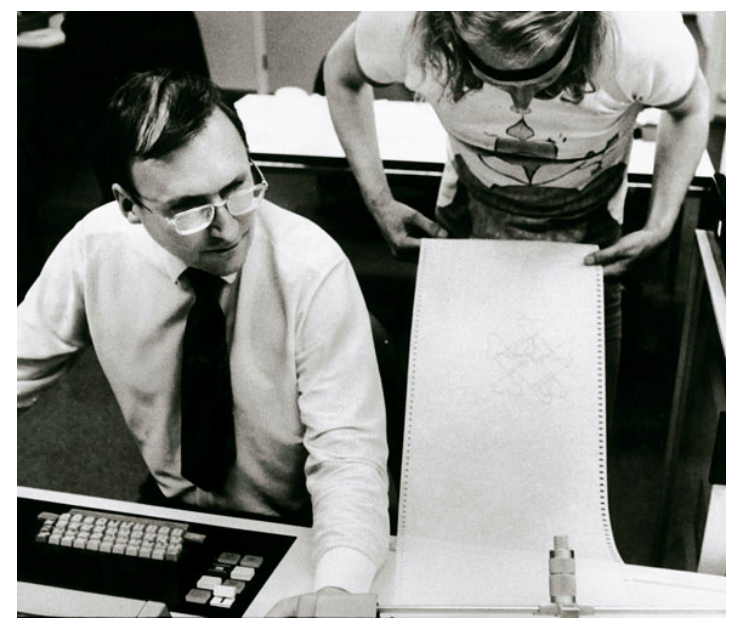

Fig. 2. Sten Kallin (left) and Sture Johannesson (right) during their work with Intra at IBM Stockholm in the early 1970s. Courtesy of Sture Johannesson.

\subsection{Case 3: Mikael Jern and Beck and Jung}

In 1965, the artist Holger Bäckström (1939-1997) and the mathematician Bo Ljungberg (1939-2007) started out on a lifelong collaboration. They called themselves Beck \& Jung and were early users of computer technology. The computer technology was specifically apt for combining their mathematical and artistic skills and their early experimentations with computer graphics have gained them an international reputation $[7,19,20]$.

Initially, they started to develop a new kind of alphabet called Bildalfabetet (the Picture Alphabet) based on a module system consisting of eleven basic forms. In 1966, Beck \& Jung began to collaborate with Leif Svensson at IBM in Malmö where they used the IBM manufactured computer IBM/1401 to examine the possibilities of Bildalfabetet. The collaboration lasted until 1967 and Felixsnurran (the Felix Pivot) (1967-1968) is one of their most famous works during this time [21].

From 1970 to 1976, the programmer Mikael Jern (b. 1946) worked together with Professor Hellmuth Hertz (b. 1920) on a project where they developed the first color plotter in the world, the Color Ink Jet Plotter [22]. The Color Ink Jet Plotter was developed because of collaboration between the department of Building Function Analysis, the Department of Electrical Measurement, and the University Computing Center at Lund University. As such, it was an important step in the development of computer graphics [7]. Jern developed the program Color that made it possible to draw color pictures and he continued to develop the idea during the years to come [23]. Jern 
was an early and ardent advocate of raster graphics, instead of vector graphics, and he argues that one way of interpreting his work with Color might be considered as a way of visualizing the advantages and possibilities of raster graphics [24]. Color was used on a UNIVAC 1108, mainly for environmental research such as visualizing community planning [7]. However, although they formed a relatively almost invisible group, a few artists used the Color Ink Jet Plotter such as Beck \& Jung. In 1972, they made their first color pictures by using the Color Ink Jet Plotter [21].

In 1979, Jern used Color to create the Color Cube (consisting of 17x17x17 small cubes). The Color Cube was a way of demonstrating the $3 \mathrm{D}$ graphics as well as visualizing the color system itself. Although the principle for the color cube had been described before, this was the first time it was possible to visualize the technique by a computer. Beck \& Jung became interested in the color cube and approached Jern to ask whether they could use it and Jern agreed [24]. The result became their project The Chromo Cube that started in 1980. Between 1982 and 1986, Beck \& Jung continued to elaborate with different forms. However, this time they worked together with Bob Wissler, a technician at Lund University, who helped them to use the program developed by Jern [21].

When Jern describes the collaboration with Beck \& Jung it becomes quite obvious that they had different roles:

\begin{abstract}
Beck \& Jung came to me and asked if they were allowed to use my programs that made these cubes. And I made the first one for them, but after that I didn't have time for it, instead there was a guy called Bob Wissler in Lund, who was a programmer, who became their programmer and helped them to use my programs [24].
\end{abstract}

This collaboration is different from the two other cases discussed in this paper, since in this case Jern had already made the program as well as the color cube for another purpose. Hence, the color cube "was used but not invented by Beck \& Jung" [7]. There is also a difference in the economical conditions surrounding the collaboration between Jern and Beck \& Jung. At the computer department, one was able to rent time at the computer according to a specific rate. There were also additional costs in relation to color prints [25].

\title{
3 Conclusion
}

In this paper, I show that the number of computers used for making art during this time was rather limited. The computers were mainly at the computer department at Lund University and large companies such as Saab and IBM. Another important place was Fylkingen. Given the conditions that the knowledge of using computers during this time was limited to a few persons, mainly engineers, we can assume that the artistic projects carried out during this time more or less required collaborations between artists and engineers. In this manner, the artists needed access to the computers as well as the knowledge of how to use them to create their artworks. However, I also demonstrate that the engineers, by participating in these collaborations, might have further developed in their role as programmers since the artist's ideas on how to use the technology often stimulated the development of their 
programming skills. This interpretation finds support in the international development during this time, as it happened that large international companies and universities supported these kinds of collaborations with the aim to foster interactions between artists and the industry; early examples are IBM, AT\&T Bell Labs, and Lincoln Laboratory at MIT [2, 26]. A later example is PAIR, the PARC Artist-in-Residence program at Xerox Parc in Paolo Alto that started in the early 1990s [27].

Initially, I claimed that early computer art was a co-construction. I would like to end this paper by suggesting that it is not only the art made by those collaborations but also the computer technology being used in the collaborations - that might be considered as co-constructed.

Acknowledgments. The author wishes to thank Stiftelsen Längmanska kulturfonden, Helge Ax:son Johnsons stiftelse and Anna Ahlströms och Ellen Terserus Stiftelse for valuable financial support. Per Lundin has given valuable comments on earlier versions of this manuscript.

\section{References}

1. Shanken, E.A.: Artist in Industry and the Academy: Collaborative Research, Interdisciplinary Scholarship and the Creation and Interpretation of Hybrid Forms. Leonardo 38, 415-418 (2005)

2. Davis, D.: Art and the Future: A History/Prophecy of the Collaboration Between Science, Technology and Art. Thames \& Hudson, London (1973)

3. Bijvoet, M.: Art as Inquiry: Toward New Collaborations Between Art, Science, and Technology. Peter Lang, New York (1997)

4. Loewen, N.: Experiments in Art and Technology: A Descriptive History of the Organization. PhD Dissertation New York University, New York (1975)

5. Hackett, E.J., et al. (eds.): The Handbook of Science and Technology Studies. MIT Press, Cambridge (2008)

6. Oudshoorn, N., Pinch, T.: How Users Matter. MIT Press, Cambridge (2003)

7. Svensson, G.: Digitala pionjärer: Datakonstens introduktion i Sverige. Carlssons, Stockholm (2000)

8. Lundin, P.: Documenting the Use of Computers in Swedish Society between 1950 and 1980. KTH, Avdelningen för teknik- och vetenskapshistoria, Stockholm (2009)

9. Portelli, A.: The Death of Luigi Trastulli: Memory and the Event. In: The Death of Luigi Trastulli and Other Stories: Form and Meaning in Oral History, State University of New York Press, Albany (1991)

10. Broman, P.O.: Kort historik över Framtidens musik: Elektronmusiken och framtidstanken i svenskt 1950- och 60-tal. Gidlunds, Hedemora (2007)

11. Morthenson, J.W.: Interview from 2007 by Anna Orrghen, medie- ochkommuni kationsvetenskap, Institutionen för kultur och kommunikation, Södertörns högskola, Stockholm

12. Sundqvist, G.: Interview from 2007 by Anna Orrghen, medie- och kommunikations vetenskap, Institutionen för kultur och kommunikation, Södertörns högskola, Stockholm

13. Bodin, L.-G.: Interview from 2007 by Anna Orrghen, medie- och kommunikations vetenskap, Institutionen för kultur och kommunikation, Södertörns högskola, Stockholm 
14. Ernkvist, M. (ed.): Svensk dataspelsutveckling, 1960-1995. Transkript av ett vittnessemi narium vid Tekniska musset i Stockholm den 12 december 2007. KTH, Avdelningen för teknik- och vetenskapshistoria, Stockholm (2008)

15. Bang Larsen, L., Johannesson, S.: Sture Johannesson. Lukas \& Sternberg, New York (2002)

16. Kallin, S.: Interview from 2007 by Anna Orrghen, medie- och kommunikationsvetenskap, Institutionen för kultur och kommunikation, Södertörns högskola, Stockholm

17. Åkerman, C.: Dekorerad IBMare gör vad han vill. Datateknik 1 (1989)

18. Johannesson, S., Johannesson, A.C.: Interview from 2007 by Anna Orrghen, medie- och kommunikationsvetenskap, Institutionen för kultur och kommunikation, Södertörns högskola, Stockholm

19. Popper, F.: Art of the Electronic Age. Thames \& Hudson, London (1993)

20. Nilsson, B., Bruhn, P.-O., Ljungberg, S.: Beck \& Jung med glada hälsningar! Torekovs Kulturstiftelse, Torekov (2009)

21. Eriksson, L., Beck \& Jung: Chromo Cube. Wedgepress \& Cheese, Bjärred (1981-1982)

22. Hertz, H., Jern, M.: Hard Copy Color Display System Using Ink Jets. Computer Graphics in Planning (1972)

23. Jern, M.: Color Jet Plotter. In: International Conference, Computer Graphics, SIGRAPHACM, vol. II(1), pp. 18-31 (Spring 1977)

24. Jern, M.: Interview from 2007 by Anna Orrghen, medie- och kommunikationsvetenskap, Institutionen för kultur och kommunikation, Södertörns högskola, Stockholm

25. Information given by phone by Ingemar Dahlstrand (August 2007)

26. Century, M.: Encoding Motion in the Early Computer: Knowledge Transfers between Studio and Laboratory. In: Broeckmann, A., Nadarajan, G. (eds.) Place Studies in Art, Media, Science and Technology: Historical Investigations on the Sites and the Migration of Knowledge, pp. 29-45. VDG, Weimar (2008)

27. Harris, C. (ed.): Art and Innovation: The Xerox Parc Artist-in-Residence Program. MIT Press, Cambridge (1999) 